УДК 821.163.41-1.09:398

https://doi.org/10.18485/godisnjak.2021.16.1

Снежана Д. Самарџија* Универзитет у Београду

Филолошки факултет
Оригинални научни рад Примљен: 10. 09. 2021.

Прихваћен: 05. 11. 2021.

\title{
„ОСОБИТО МИТОЛОГИЧКЕ” ПЕСМЕ У ЗБИРКАМА ВУКА КАРАЏИЋА
}

Од 1841. када је Вук приредио први том бечког издања Српских народних пјесама, руковет митолошке лирике је засебно издвојена. И у овом случају те су варијанте представљале Вуков антологијски избор. Део записа остао је међу рукописима, а неколико сличних текстова придружио је другим лирским врстама. Међутим, Вуков однос према тако одређеном сегменту српског усменог песништва и традиције био је много сложенији. Овом приликом разматрају се Вукова полазишта при разврставању грађе, уз указивање на стилизацију, поетичке законитости врсте и жанровску флексибилност.

Кључне речи: лирске митолошке песме, слојеви традиције, Вукова класификација, жанровска прожимања, формула.

За разлику од обе Пјеснарище и прве књиге Лајпцишког издања $\mathrm{Ha}$ родних српских пјесама, Вукова класификација народне лирике била је знатно развијенија када је склопио коначно, Бечко издање, обухватајући „различне женске пјесме”. ${ }^{1}$ Међу двадесет врста тада је издвојио као тринаесту „Пјесме особито митологичке”. Вукова интересовања за овај сегмент српске традиције свакако су покренута под окриљем немачког романтизма. Утицаји су нарочито били последица сарадње са Јакобом Гримом, аутором Немачке митологије (1835) и зачетником митолошке

*markosoft91@gmail.com

${ }^{1}$ О томе више: Недић 1975: 627-646; Krnjević 1986: 210-279. 
теорије о пореклу приповедака од остатака митолошког система из индоевропске колевке. ${ }^{2}$

Не треба посебно доказивати да ни 1818, ни 1852. у Вуковом Српском рјечнику не постоје појмови митологија и мит ${ }^{3}$. Ипак, седамнаест одабраних записа који чине митолошку руковет ${ }^{4}$ само су део овог корпуса. Неколико варијаната „залутало” је међу најбројније, љубавне песме, ${ }^{5}$ a неке су остале у рукописима. ${ }^{6}$

Иако је јасно обележио особито митологичке песме у склопу лирике, Вук је исти термин употребио и за другачије обликоване варијанте. Завршавајући о Мученицима 1841. у Бечу кратак, нови предговор за први том Српских народних пјесама, настојао је да и за следећу збирку заинтересује читалачку публику. Уопштено је најавио да ће се ту наћи „пјесме јуначке од најстаријих времена до пропасти царства и господства српског”. Издвојио је и „девет, понајвише побожнијех и особито митологичкијех, којима се не зна старина (у једној се од њих спомињу дивови)" (Караџић 1975: 45). Тиме је обухватио легенде и бајке у стиху, односно подврсте „пјесама на

${ }^{2} \mathrm{O}$ улози В. Грима за Вуков рад, сакупљања српске фолклорне грађе и упознавање немачких кругова са српском баштином в: Мојашевић 1950; Koljević 1982: 111-140.

${ }^{3}$ Именица мит илуструје природу језичког материјала и процесе у којима се богате, сасвим мењају, а често и заборављају значења појединих појмова. Јер, 1818. и 1852. уз одредницу мит наведен је латински превод largitio - подмићивање, уз додатне Вукове примере: cyди по миту, узима мит (Караџић 1966: 403; 1986/1: 505). Исто значење има и именица мито, поткрепљена 1852. дистихом из стиховане легенде о гресима, грешницима и њиховим мукама на ономе свету (Караџић 1988: 4, $36-37)$.

${ }^{4}$ Од бр. 223 до 239: Вилине пјесме (три), Вилина посестрима, Јунак вилу устријели, Вила зида град, Мома и вила, Преља на вилину бунару, Сунце и мјесеи просе дјевојку, Женидба сјајнога мјесеца, Опет женидба мјесечева, Сунчева сестра и паша тиранин, Сунчева сестра и цир, Цар и дјевојка, Нечувени послови, Особити орач, Изједен овчар, Љуба огњевита и Љуба змаја огњенога.

${ }^{5}$ Посебно се кроз сагледавања остатака архаичних представа могу истраживати сложена значења појединих слика, формула и варијаната које припадају различитим лирским врстама: 244. Преди, момо, дарове; 266. Секула и вила; 376. Калопер Перо и вита Јела; 400. Стара неће, а млада хоће; 416. Дјевојка и суние; 431. Част гостима; 432. Најбољи лов; 468. Анђа капииија; 469. Краљь и бан код кола; 505. Не отимљи, већ ме мами; 664. Јабука и вјетар; 665. Босиљак и роса; 668. Жалостна ткаља Јања; 669. Мутан Дунав; 670. Момче и гоние итд.

${ }^{6}$ Љ. Стојановић је за пету књигу Државног издања Вукове збирке приредио још осам записа и штампао под истим засебним поднасловом (од. бр. 250 до 257: Љуба змаја огњенога, Оклад виле и ђевојке, Вилин чудесни град, Мјесеи и сунце, Особито накићена пастирка, Женидба Несијевић Јова и Лијек Будимске краљице, Караџић 1898/V). По истом принципу су Ж. Младеновић и В. Недић груписали преостале рукописне варијанте (од бр. 101 до 109: Суние, мјесеи и киша, Суние и дјевојка, Опклада суниа и дјевојке, Женидба сјајнога мјесеиа, Браћа сестру удају за муғьу, Вилин дар, Анђа и виле, Круна од злата и Дјецуа кад пада киша, Караџић 1973/I). 
међи" лирике и епике 7 , мада су ликовима вила и змајева, оностраних и природних сила, богова, светаца и јунака дивовског стаса, а змајевитог порекла, припадале бројне улоге у целокупном усменом стваралаштву Срба и културама свих народа света.

\section{1. Бајословље или митологија}

Током историје изучавања усменог стваралаштва на јужнословенским просторима „случај” митолошких песама постајао је све комплекснији, тим пре што је најчешће примењивана наджанровска истраживачка перспектива. Такав приступ омогућавале су саме умотворине, јер су и независно од поетичких законитости обухватале мноштво детаља, подстицајних за истраживања српске, хрватске, словенске паганске религије. Митолошке песме су проучаваоцима биле један од извора за повезивање расутих честица из древних епоха, а синтезе су се махом односиле на архаичне сегменте традицијске културе. Разматрани су, на пример, елементи соларног и лунарног култа; представе о митским бићима; митска „философија” итд.

Од половине 19. века словенски пагански пантеон привлачио је пажњу сакупљача умотворина и научних ауторитета. Иван Кукуљевић Сакцински, Станко Враз, Људевит Гај, Матија Ваљавец - на основу прозне грађе, певања и веровања пишу студије посвећене старој словенској митологији и различитим митским бићима (нпр. о вилама, суђеницама и др; Bošković-Stulli 1978: 290, 294, 310). Издвајајући низ процеса битних за живот и генезу традиције, Ватрослав Јагић је миту Јужних Словена прилазио на основу фолклорног фонда, лексике, писаних споменика и увида у баштину других народа. Мада је тако интензивније осветљавао народну прозу, закључио је, на пример, да персонификација природних сила представља извор сваке митологије: „Nema sumnje da se je također suncu, mjesecu, vjetrovom itd. božansko štovanje iskazivalo (...) U narodnim pjesmama pominje se: ženidba sunca i mjeseca, zna se za sunčevu sestru i majku, govori se nešto i o živom ognju" (Jagić 1867: 21). А, као непосред-

${ }^{7}$ „Һекоје су пјесме тако на међи између женскије и јуначкије, да човек не зна, међу које би и узео (...) Оваке су пјесме наличније на јуначке, него на женске, али би се тешко чуло, да и људи пјевају уз гусле (већ ако женама), а због дужине не пјевају се ни као женске, него се само казују.” (Караџић 1975: 560). Вук их је тако и распоредио, на крају прве и с почетка друге књиге Бечког издања, при чему је ту било више побожних и митолошких варијаната од девет најављених. Веома разноврсне и међусобно (Караџић 1988: $1^{\circ}-22^{\circ}$ ), ове лирско-епске песме (према савременим класификацијама које нису потпуно усаглашене) илуструју особености стихованих лагенди, бајки у стиху и балада. 
но сведочанство о религијском синкретизму, навео је, такође на основу усменог песништва и писаних споменика, везивање атрибута паганских божанстава за имена хришћанских светаца (Jagić 1867: 90-91). У том духу је, примера ради, један оглед о сунцу штампан међу бројевима Vienca 1873. Аутор, скривен иницијалима М. К, запажања аргументује помоћу целокупне фолклорне грађе, покушавајући да из поезије, казивања и обреда досегне до старинских богиња и богова. Реконструкцији бајословља је нарочито посвећен Натко Нодило, чија тумачења варијаната, тема и ликова, уз примере из светске митологије, излазе у Radu JAZU од 1885. до 1890, обједињени јасним насловом Religija Srba i Hrvata, na glavnoj osnovi pjesama, priča i govora narodnog. Иначе један од заговорника митолошке теорије о пореклу мотива (Милошевић-Ђорђевић 1980: 495-500), Нодило је српску и хрватску фолклорну грађу првенствено посматрао као остатке митских представа о небеским телима, календарској години, представницима пантеона и култу мртвих (Nodilo 1981). Митолошка теорија утицала је и на тумачења Илариона Руварца, само што су се она више односила на „проучавања наших јуначких песама као саставног дела индоевропске језичке и митолошке заједнице" (Сувајџић 2007: 35).

На преласку 19. у 20. век истраживања традиције, обичаја и народног живота подстицале су и научне институције, што долази до изражаја међу годиштима Zbornika za narodni život i običaje Južnih Slavena (JAZU) и Српског етнографског зборника (СКА). За фолклористику је био значајан и Караиић Тихомира Ђорђевића, као и Ђорђевићева истраживања српске традицијске културе. ${ }^{8}$ Сличан, парцијалан приступ појединим сегментима фолклорне баштине и увид у богату грађу имао је и Сима Тројановић, док је Веселин Чајкановић покушао да реконструише целокупан систем старе српске религије и митологије. У радовима и монографијама ових научника митолошке песме нису примарна истраживачка област, већ заједно са свим осталим усменим врстама, детаљима из живота српских средина и култура других народа пружају ослонац при сагледавању старих и најстаријих слојева националне баштине.

Последњих деценија прошлог миленијума фолклористичка истраживања укључују и извесне неомитолошке тенденције. Без претензија да се реконструише древни пагански систем, овакви приступи се односе на поједине сегменте народне књижевности и/или шире обухваћен феномен

${ }^{8}$ Такве прегледне монографије нпр. о природи, вилама и вештицама; деци; злим очима итд. тематски су усмерене ка једном феномену баштине, а истраживања и закључци темеље се на богатом материјалу. 
традицијске културе. ${ }^{9}$ Анализе су потврдиле велику продуктивност митске матрице при обликовању тематско-стилског фонда усменог стваралаштва. Такође су се указали и процеси важни за трајање ,једноставних облика" - од религијског синкретизма, преко чврстих спона митологије и обреда, до семантичког богатства појединих слика и симбола.

\section{2. Особито митологичке пјесме}

Митолошке песме, као подврста усмене лирике, осветљене су и засебно, а појединим варијантама и тематским круговима посвећена је и особита пажња, уз евентуална указивања на поступке стилизације архаичних подлога песничких слика. ${ }^{10}$

На крају сведеног прегледа лирске народне поезије Павле Поповић набраја песме „опште важности (...) То су такозване митолошке, религиозне, али од старе вере о вилама, сунцу и месецу итд”. Њима придружује „религиозне хришћанске, у којима се описују душевна стања Богородице, Исуса, апостола" (Поповић 1931: 54-55). Утицај Поповићевих приступа испољавао се и при разматрањима митолошких песама у предговорима избора, намењених ширем кругу читалаца.

Састављајући једну такву Антологију или „уџбеник”, и користећи већи број извора, Јаша Продановић не издваја митолошку лирику. Одабране варијанте део су одељка под насловом Побожне и моралне песме, односно „верске и моралне” (Продановић 1938: 74-91; 8). Примарно полазиште, осим поучне тенденције, представља и категорија ликова, а Продановић набраја песме „о Богу, Богородици, Христу, свецима и анђелима”. Узгред напомиње како се „приказују сунце, месец, звезде и ветрови

${ }^{9}$ В: Детелић 1992; Лома 2002. Такође: тематски зборник из 1996. посвећен миту. Осим уводне студије (Детелић 1996), у засебном одељку - Мит - фолклор осветљене су следеће теме: А. Прокопиев, Сказната и митот; М. Буюклиева-Стопчева, Някои успоредиии на името Дионис в календарно-обредния ичикьл на Славяните; Л. Лашкова, Из бугарске и српске митолошке терминологије; Н. Љубинковић, Митолошка основа јеремијских песама; 3. Карановић, Митологија биља у српској народној лирској поезији; Љ. Пешикан-Љуштановић, Песма о девојци која је запалила село у светлу веровања о змају - кишодавиу; М. Дрндарски, Митолошки елементи у песмама типа Краљевић Марко и вила бродарица; М. Матицки, Митска основа епске вертикале Марко Краљевић - Карађорђе; Д. Ајдачић, Патриотска ремитологизаиија вила у къижевности српског романтизма; В. Пирузе-Тасевска, Мит и македонска народна приказна; Л. Магду - М. Пуја, Мит у румунској народној књижевности; О. Плужаров, Симболи свадбених обичаја и њихова веза са митовима, бајањима, легендама и веровањима. У овом зборнику в: Б. Шијаковић, Mythos - селективна хронолошко-тематска библиографија о теоријама мита и хеленском митотворству.

${ }^{10}$ В: Павловић 1982: 193.212; Krnjević 1986: 127-134; Петковић 2007: 62-77; Сувајџић 2008: 111-137; Карановић 2010: 59-70. 
као људска бића. Има још у тој поезији натприродних бића и тајанствених сила: вила, змајева, аждаја, дивова, који човеку чине некад добро а некад зло. - У некима се показује веровање у чини и уроке, судбину и снове, слутње и предсказања и у претварање живих личности а и мртваца у животиње и биље” (Продановић 1938: 8).

Војислав М. Јовановић је издвојио „песме митолошке”, наглашавајући њихову старину: „Као најстарије по предмету који се у њима опева, сматрају се песме митолошке, које потичу из старих народних веровања о вилама, о сунцу и месецу, о разним природним појавама, којима се приписују божанске или натчовечанске особине; трагови тих веровања налазе се и у другим лирским песмама, а врло често и у епским; тих песама нема много, и у колико их има, у садржину њихову увукле су се и друге новије појединости, из хришћанских веровања или из дневнога живота, тако да оне данас имају готово искључиво забавно обележје" (Јовановић 1937: XXI). ${ }^{11}$

Из међуратног периода је и покушај Димитрија Ђуровића да сачини популарну систематизацију народних умотворима. Упркос педантно изведеној композицији ове књижице, излагање „података” далеко је од прегледног представљања сложених питања. То управо илуструју одељци посвећени митологији, у којима се парафразе митолошких песама (нпр. Ђевојка и суние; Сунчева сестра и пама тиранин; Сунчева сестра и иар) представљају као „бајке” (Ђуровић 1931: 25, 28-30). Посебан одељак посвећен је „словенском миту о необичном сејачу”, док остаје нејасно на које се песничке врсте и варијанте односи поднаслов „песме митолошког циклуса" (Ђуровић 1931: 34-36, 45-46).

Жива интересовања за ова питања, нарочито између два рата, ${ }^{12}$ током следећих деценија махом се не настављају. Заборављени су, на пример, огледи Светислава Стефановића, посвећени митолошким темама и песмама наше народне поезије (Стефановић 1933: 201-209). Осветљавајући природу стилизација сунчаног мита, Стефановић посматра народне песме и приче као сачуване споменике ,једне културне епохе давно већ прошле и угашене”. Процесе илуструје честом темом какву чини „свадба и свадбени обичаји небеских тела односно божанстава [који] постају модели људских свадбених обичаја и обратно, сватовске песме људске пренете на небеске

${ }^{11}$ Јовановићева подела народне лирике садржи десет врста (митолошке, побожне, слепачке, обичајне, домаће, љубавне, посленичке, о природи, пригодне, шаљиве и подругљиве). Мада је касније прихваћена другачије заснована класификација, занимљива је руковет песама „о природи”, које нису више засебно издвајане.

${ }^{12}$ Ћоровић 1908: 69-79; Ђурић 1923: 976-995 и 1925, Стефановић 1933. 
свадбе ушле су у религиозне ритуале, да би најзад добиле тако симболична и спиритуална тумачења..." (Стефановић 1936: 35-36). Скрупулозно наводећи податке о истраживањима тих области, Стефановић прати сличне обраде у традицији других народа, а осим небеске свадбе скреће пажњу на песме о сунчевој сестри и везе митолошких, богојављанских, божићних и сватовских лирских врста.

И друге занимљиве студије из међуратног периода касније су занемарене. Некада је повод за то представљао шири опус научника, какви су били Владимир Ћоровић и Милош Ђурић или значај Чајкановићеве реконструкције старе српске религије, а удела су имали и разлози политичко-идеолошке природе.

Од педесетих година прошлог века фолклористи су највише заинтересовани за епско песништво. Ипак, Војислав Ђурић је управо митолошке песме, заједно са другим лирским и прозним врстама представио као део најстарије етапе развоја људског друштва. Покушавајући да „помири” оновремене идеолошке тенденције са објективним разматрањем традиције, приклонио се компаративном приступу, у којем је већу предност дао културама племена Аустралије и Полинезије него српској, југословенској или јужнословенској грађи. Одлично упориште за такав приступ представљало је упознавање наше публике са Фрејзеровом Златном граном, уз драгоцен списак литературе у склопу поговора (Ђурић 1954: 21-25 и 116-118). Догађало се и потпуно изостављање митолошких песама из антологија и прегледа народне књижевности (Матић б. г.).

При разматрањима митолошке песме као особене песничке врсте, више долазе до изражаја тешкоће класификације усменог стваралаштва, него што су истакнуте поетичке „константе”. Према приступу Владана Недића, митолошке, хришћанске и слепачке песме заједно чине засебну категорију верских песама. Недић, међутим, истиче двоструку природу митолошких представа. Њихово исходиште је у паганском систему, чији се елементи рефлектују и кроз стихове певане током разних обреда, али и међу казивањима демонолошких предања. С друге стране, призори везани за оностране светове не одражавају само прастара веровања, већ и свакодневни живот и „чиста људска осећања” (Недић 1977: 21). Истом појму Недић је пришао и на другачији начин, истичући да је у митолошким песмама изразит „drevni sloj narodne književnosti nastao u doba paganskih verovanja”. Али, ти дубински талози су обликовани „роtpunije u narodnoj epskoj pesmi, negoli u obrednim pesmama i bajkama." Недићев приступ категорији ликова и тема чини још сложенијим сам појам митолошке песме: „To su prvenstveno pesme o bogovima, njihovom rođenju, bitkama, propasti 
i smeni, o ženidbi sunca i meseca; o sunčevoj sestri, o divovima, zmajevima, vilama, vukodlacima, o podzemnom svetu mrtvih, o 'zmiji mladoženji', o uziđivanju ljudske žrtve; o 'mrtvim pohođanima'" (Nedić 1985: 441).

И Видо Латковић митолошке и хришћанске лирске врсте обухвата широм одредницом религиозних песама. Латковићева тематска систематизација, заправо, такође почива на каталогу мотива и ликова. Тако су издвојени „кругови” митолошких песама о вилама, змајевима и аждајама, сунцу, сунчевој сестри и месецу, небеским телима, схваћеним „као нека велика породица" (Латковић 1975: 179). Указује се, с правом, на жанровску флексибилност ове песничке форме, јер варијанте могу бити засноване на „празноверици” и веровањима у снагу речи, погледа или тајних моћи биља, а приближавају се етиолошким легендама, посленичким песмама, исказивањима љубави и морално-поучно интонираним стиховима (Латковић 1975: 176-181).

Песник Миодраг Павловић сагледао је целокупну усмену лирику у контексту стилизованих честица митског комплекса. Такав приступ није се испољио само у избору и распореду грађе, већ и на страницама предговора Антологији, а нарочито у завршном сегменту при тумачењу „трију митолошких народних песама” (Женидба сјајнога мјесеца, Вила зида град и Вилин чудесни град, Павловић 1982: 193-212).

Међу издвојеним појмовима из области народне књижевности Нада Милошевић Ђорђевић истиче да су митолошке песме „uslovan, dosta neodređen i neujednačeno upotrebljavan termin za lirske, epske pesme i balade, koje su očuvale ili naknadno uvele likove, događaje i shvatanja iz starih mitoloških sistema" (Milošević-Đorđević 1984: 163). Дефиниција је обухватила динамичне процесе, својствене животу традиције, а заснована је на разноликом приступу проучавалаца и Вуковом комплексном односу према овом, очито, тематско-жанровски разгранатом комплексу.

У антологији српске усмене лирике Зоја Карановић је митолошке песме груписала са хришћанским и слепачким међу религиозне или верске песме. Доделила им је почасно место, указујући на старину космогонијске тематике, уз приближавање правремена стварања и виших сила догађајима „у 'садашњости' у којима су јунаци људи”. Наглашавајући да песма не може да се поистовети са митом, Зоја Карановић истиче као битну одлику митолошке лирике „опште осећање повезаности свега што у свету постоји, у космичкој драми учествују природне, божанске и људске снаге, у песничком кључу коментаришући сферу праузрока" (Карановић 1996: 257). Указујући истраживачким захватом на древне слојеве и снагу „архајског митско-метафизичког сензибилитета", делотворног и међу осталим лир- 
ским врстама, Зоја Карановић се задржава на нијансама које песничке облике разликују: „док митолошке лирске народне песме, описујући делатности богова и натприродних бића, асоцирају стварање света, остале (...) врсте певају о његовом сталном обнављању" (Карановић 1996: 308). О важности ових питања за сагледавање целокупне традицијске културе и усменог песништва речито сведочи и наслов који је Зоја Карановић дала мозаично склопљеној монографији - Небеска невеста (Карановић 2010).

\section{3. Девице и демони „особито митологичких пјесама”}

Вуково означавање митолошких песама проблематично је више на нивоу терминологије, него по распореду грађе у збиркама. Разликовање „женских” митолошких песама од мање-више сродних лирско-епских обрада заснивао је на полазиштима која је примењивао и при систематизацији осталих умотворина. Битан је био начин обликовања слике/ радње, односно сажетост или развијеност композиције. Разврставањем „по дужини” руководио се и при општој класификацији народне поезије и приповедака. ${ }^{13}$

Други критеријум подразумевао је тематику, што поред Вукове „деобе” епског песништва, потврђују и одељци посвећени предањима у Животу и обичајима народа српског. Груписања по тематским круговима заснована су, заправо, на категорији јунака, због чега се не могу са истоветним „учинком” применити на све усмене облике. Овако изведена „деоба" епике (уз хронолошки „распоред” на старија - средња - новија времена) јесте, до извесне мере, прегледна. Међутим, кроз статус типских ликова и „покретљивост” мотива из ширег фолклорног фонда не испољавају се само жанровске законитости, већ и међусобна блискост усмених врста. То одлично илуструју различите обраде појединих мотива (нпр. вила љубовца), али и супституције носилаца радње у склопу истих модела (нпр. змајеборство - двобој против Арапина/отмичара). ${ }^{14}$

За обе митолошке „скупине” међу „женским пјесмама” и врстама усменог песништва „на међи” својствено је активирање представа из старијих, дубинских слојева традиције. Јунаци ових варијаната некада јесу девојке и момчад, цареви и пастири, преље и орачи, али њихове судбине усмеравају више силе. Ти представници других светова обликовани су

${ }^{13}$ Вук је међу првима, при разврставању народних приповедака, указао на удео композиције, уз улогу хумора и приказивање „чудеса” и/или реалистичних догађаја: „Мушке приповијетке опет би се могле раздијелити на дугачке и кратке” (Караџић 1988а: 48).

${ }^{14}$ О томе више Милошевић Ђорђевић 1971. 
кроз персонификацију небеских тела и природних појава (Сунце, Месец, Даница, Преодница, муња, гром, киша), као онострана бића (вила, змај), људи са демонским моћима ${ }^{15}$ (вештица) или умрли који привремено походе живе. Заправо, два универзума су у непрекидној интеракцији, оствареној на више начина. Мада су обе „стварности” раздвојене, границе се превазилазе, а сам чин прелаза има и обредне компоненте, уз позитивне и негативне последице контакта.

Човек јесте у подређеној позицији, а представници митских сфера према њему успостављају амбивалентан однос. Наклоност, награда или казна произилазе из опхођења смртника, независно од друштвених сталежа чији су представници. Такве осцилације односа између два света, повезане са карактеризацијом њихових представника, својствене су и стилизацији бајке. Али, од бајке их дели дистанца колектива према тематици, односно доживљај „чуда” (бајка) или проблематизација фантастике (митолошке песме). На нивоу ликова митолошка лирика је сродна и врсти предања о оностраним бићима и веровањима у „ствари којијех нема”, како би рекао Вук. Неке обраде блиске су и „тумачењима” својственим етиолошким предањима. Међутим, док девојке и момци из митолошких лирских минијатура могу бити и супериорни у односу на Сунце, виле и змајеве, у предањима је сусрет светова погубан за човека.

Независно од атрибута и номенклатуре по којој се онострани ликови разликују од смртника, обичаји и схватања колектива пројектују се на судбине и животе тајанствених, видљивих и невидљивих бића. Више силе, премда живе на небу, у облацима, уврх гора или на крају света, окупљају се, жене и удају, умиру и рађају, путују и враћају се, ратују, бране се, чезну, завиде и свете. „Пресликани” хармонични односи патријархалне задруге упадљиви су посебно при варирањима свадбених ритуала. Било да се брак склапа између небеских тела и природних појава или је уведена и њихова особита изабраница, свадба испољава космогонијске обрисе, јер се тим чином успостављају поредак и хармонија у природи.

Процес инверзије узрока и последице и овде се манифестује, али другачије од друштвено-историјске перспективе из епског песништва. ${ }^{16}$

${ }^{15}$ О томе више Зечевић 1981: 9, 137-146, 184.

${ }^{16}$ Нпр. генерације памте владаре из лозе Немањића, од којих је већина добила и светачки ореол. Полазећи од тог знања, певачи стилизују варијанте које се „временски” померају ка првим деценијама успона династије (Караџић $1988: 23^{\circ}, 24^{\circ}$ ). Када спозна заслуге идеалног владара - „цар Немање”, хришћанска господа благосиља цео његов род. Или, распад српског царства започиње непосредно након смрти првог цара. Из таквих околности „тумаче” се лик његовог наследника и епитет везан за име - Урош Нејаки. По представама певача и колектива цар Душан одлази са овога света док је његов син у колевци „од четр'ес дана” (Караџић 1988: 
Свадба, као један од обреда прелаза (Ван Генеп 2005: 134-167), обавља се по земаљским „правилима”. Старешина куће бира невесту; највиђенији међу сватовима имају улоге кума, старог свата итд, обавезно је даривање. Међутим, изгледа као да смртници само опонашају оно што је човечанство добило у правремену стварања, када се обавила Прва света свадба. Кроз утисак обрнуте перспективе (човек $\rightarrow$ више силе; човек $\leftarrow$ више силе) и тако детерминисано човеково поимање сопственог места у друштвеним конвенцијама и ритму природе долази до изражаја међусобна упућеност митолошких представа и обредне праксе - тј. митолошке и обредне лирике. Од како је створен свет, након небеске свадбе, ритуал се понавља сваки пут када млади пар, уз благослов рода, заснива нову брачну заједницу. Ипак, тематика има наджанровски статус, те се митолошке песме о небеским сватовима, змају отмичару, вилинској лепоти и сл. приближавају и другим усменим врстама. Примера ради, свадбена лирика обухвата поређења невесте и виле, као што је међу спасовским песмама стилизован мотив о девојци коју уграби змај, али га она надмудри.

Ако устројство космоса почива на призорима Прасвадбе и човекове делатности на овоме свету могу бити представљене у мање-више сличном поретку. Божија мајка омогућава обављање ратарских послова када особитог или, можда, Првог орача обдари: воловима, јармовима, палицама, заворњима, бичем и ручконошом. Поред тога што се сматрало да је сам чин орања „религијска радња” (Чајкановић 1994/5: 64), сваки од ових дарова се додатно онеобичава, ${ }^{17}$ што појачава мистичност и митске обрисе слика:

„Ко ти даде младе воке,

Младе воке, витороге?

И јармове јаворове,

И палице шимширове,

И заворње босиљкове,

И бич косу девојачку,

Љуту гују ручконошу" (Караџић 1975: 236º).

Отворено је питање саме природе дародавца. Премда се Божија мати у млађем слоју традиције „распознаје” као Богородица, божанска мајка из ове варијанте ближа је поимању Велике мајке из древних религија. Заборављено је, временом, име женског врховног божанства старог

$\left.33^{\circ}\right)$. Маркова епска слава „објашњена” је као последица благослова и клетве које добија од кума и оца при одлучивању о наследнику царског трона. Исход Првог косовског боја предочен је као неминовност Божије воље и одлуке донете пре но што је сукоб војске започео итд (Караџић 1988: $34^{\circ}, 46^{\circ}$ ).

${ }^{17}$ О томе више: Карановић-Пешикан-Љуштановић 1994: 29-32; Сувајџић 2005: 101-103. 
словенског пантеона, али се нису измениле моћи какве поседују Астарта, Аџист, Аматерасу, Изида, Изанами, Иштар, Геа, Хера, Јунона, Фрига.

Док обраде космичке свадбе укључују процесе прожимања паганске религије са хришћанским представама, целокупној митолошкој лирици својствени су рефлекси матријархата. ${ }^{18}$ Доминација женског принципа долази до изражаја управо у категорији ликова (Даница жени брата Месеца; сунчева сестра је моћнија од царева, божија мајка или вила дарују смртнике; виле зидају градове итд), чије су улоге пресудне при обликовању дијалога, описа или сведених, наговештених лирских ситуација. Женски ауторитет обједињује култ плодности са представама о господарици смрти. Двострука, а противречна својства, карактеристична за архаичне религије, испољавају се кроз опречне исходе песама о вилама - неимаркама (Караџић 1975: 226우 Караџић 1898: 252), али и при варирањима представа о огњевитој љуби, сунчевој сестри, лепоти Босиљке девојке и танковите девице, о моћима девичанске ратнице под самур-калпаком или знању немуштог језика чобанице Јане, чак и при опису Анђе капиџије (Караџић 1975: $232^{\circ}-235^{\circ}, 238^{\circ}-239^{\circ} 468^{\circ}$; Караџић 1898: $257^{\circ}$ ).

Ма колико била у сфери индивидуалног доживљаја, сама лепота је истовремено, а независно од епохе или развоја културе, део колективних канона, узора и идеала. Премда се у фонду фолклорних формула подразумева склад физичких особина и духовних врлина, лепота-девојка из лирског песништва приказана је на више начина. Сама њена појава оставља утисак нечег надземаљског, што не може бити од овога света:

„Ај ђевојко, душо моја!

Што си тако једнолика

И у пасу танковита?

Кан' да с' сунцу косе плела,

А мјесецу дворе мела." (Караџић 1975: 235).

Мада је Вук овој варијанти придодао наслов Нечувени послови, задаци које девојка обавља су уобичајени женски послови. Кодекс патријархалне задруге није нарушен, већ се просторним „измештањем” ка небеском своду тумачи особитост лепоте као награде за кротку и вредну девојку. Међутим, лепотица не самерава сопствени изглед кроз личне заслуге, већ истиче снагу космичких процеса. Њен исказ је, заправо,

${ }^{18}$ То се може посматрати (најмање) на два начина. Први приступ води ка распознавању стилизованих рефлекса одређене етапе развоја културе. Истовремено, могуће је разматрати и елементе поетичког система. Јер, за разлику од епских обрада, где се кроз јавну сферу акција глорификује мушкарац, међу лирским врстама, подврстама и темама пажња је најчешће усмерена према жени, невести, девојци, њиховим особинама и емоцијама. 
донекле и нејасан, али је изразита сличност са (свадбеном) завршницом варијанте о вилином граду на облацима:

„Нисам сунцу косе плела,

Нит' мјесецу дворе мела,

Ван стајала, те гледала,

Ђе се муња с громом игра:

Муња грома надиграла

Двјема трима јабукама

И четирма наранчама."

„... Ђе се муња с громом игра,

Мила сестра су два брата,

А невјеста с два ђевера:

Муња грома надиграла,

Мила сестра оба брата,

А невјеста два ђевера" (Караџић 1975: 226º).

Наспрам стабилности формуле у митском контексту, изразита су одступања од истицања врлина српске девојке, чију смерност не угрожавају ни природне стихије. Она обара свој поглед током невремена, док све остале девјке посматрају „Ђе се муње вију по облаку”. Када је другарице питају зашто тако поступа, Милица одговара:

„Нит’ сам луда, нит’ одвише мудра,

Нит' сам вила, да збијам облаке,

Већ ђевојка, да гледам преда се” (Караџић 1975: 599).

Као супротност таквом узорном опхођењу, управо међу митолошким песмама се најизразитије испољава самосвест лепоте-девојке. ${ }^{19}$ Некада је изразит продор социјалних реалија, те је разметљива лепотица уједно из тако богате куће да „Море говорити што јој је драго!” (Караџић 1973: $102^{\circ}$ ). Пркосно изазивање сунца при одмеравању лепоте приближава се сфери антипонашања (оцеубиство, инцест, превара, обљуба, крађа), по којој се успостављају пресудне разлике између онога што је допуштено божанствима и вишим силама, а забрањено људима.

Изазов упућен сунцу некада алтернира са такмичењем између девојке и виле. Но, независно од именовања ривала, девица побеђује најчешће по лепоти, уз евентуалне похвале њеној марљивости. У таквим околностима она може постати посестрима митског бића, а вила потврђује пораз дарујући победници „траве од помаме”, заштити јој драгог и сл. (Караџић

${ }^{19}$ Према тумачењима 3. Карановић, оваква самохвала одражава нарцисоидну фазу у психолошком сазревању јединке. Карановић 2021. 
1898/V: $251^{\circ}$ ). Опречан исход имају баладичне обраде о красној девици, коју виле одводе са собом (Караџић 1973/I: 107). Поенте варирају, али су (смртне) лепотице придружене оностраним силама, тим пре што су њихове чари опасне:

„Од сунца ми травица вехнаше,

Од ђевојке срце у јунака" (Караџић 1973/I: 103º).

И када су пасивне, попут невесте, девојке-жене из митолошке лирике постављају се у средиште радње/слике. Једна од тих сложених митских представа испољава се кроз сведен опис Анђе капиџије. Њена гранична позиција - у висинама, а на међи светова, заправо се подређује атрибутима:

„Високо се соко вије,

Још су виша граду врата;

Анђа ми је капиџија:

Сунцем главу повезала,

Месецом се опасала,

А звездама накитила" (Караџић 1975: 468)

И, премда ова дескрипција открива прожимања исконских представа са одличјима приписаним Богородици (Петковић 2007: 62-77), женско начело, у сваком случају, одражава и омогућава хармонију космоса. ${ }^{20}$ Околности прастварања нису експлицитно предочене, али и на такве творачке моћи (и функције) указују стилизоване представе и симболи из поезије других словенских народа. ${ }^{21}$

${ }^{20}$ На први поглед, противречне су интерпретације посвећене значењима и изворишту формула, које су у средишту дескрипције Анђе/Маре. Контрадикција је последица различитог поимања темпоралне перспективе и стваралачког чина. Јер, време настанка текста и бележења варијанте ретко се када подудара са временом постанка одређене представе. Иако могу потицати из (хронолошки) различитих слојева традиције, (сродне) слике, симболи и стилска „решења” припадају општем фолклорном фонду. Примера ради, о Божићу је хришћански бог заменио младо, тек рођено сунце. По истом „механизму” Богородица је могла наследити атрибуте небеске девице која ствара васиону и/или успоставља поредак небеских и земаљских светова.

${ }^{21}$ Особита значења могу имати мотиви девојачког веза. Након успостављене аналогије између брезе и девојке, пажња се усмерава на простор и, нарочито, симболику ручног рада:

„Ты сидела бы, сидела

В золотом тереме,

Ты шила бы, вышивала

Золоти узоры.

Как и первый-то узорец -

Светел месяц,

Как и другой-то узорец -

Красное солнце,

Как и третий-то узорец - 
Анђа на границама светова представља отелотворење самог небеског пространства и устројства космоса. Али, када се вертикална оса универзума „положи” у хоризонталну раван (Meletinski b.g: 253-254) измене су готово неминовне. Архаична компонента постаје замагљена, мада је још увек присутан соларно-хтонски потенцијал митског призора. То илуструје варијанта о чобаници, која напаса - два јелена:

„У сунце је обучена,

Звијездама запучена,

А даницом опасана,

Преодницом превјешена,

На чело јој мјесец сјаје" (Караџић 1898: 254).

Слика - формула као да је изгубила пређашња значења, тако да извесна семантичка празнина мора бити надокнађена. Један ток тих процеса заснива се на рационализацији митске подлоге, уз продор елемената љубавне лирике.

Након описа заносне лепотице, други (млађи?) композициони члан обликује се увођењем ликова тројице посматрача. Из мушке перспективе, градацијски се истиче утисак који лепота девојка оставља на три делије. Њихова чежња и распламсала страст постаје смисаона доминанта, довољно снажна за жанровске модификације и демитологизацију иницијалне дескрипције. То још боље открива усхићење три дилбера, који гледају чедну девојку:

\footnotetext{
Часты звезды";

„До что за этим столом да красна девица сидит,

Да красна девица сидит Иринья Павловна.

Да она шила-вышивала тонко бело полотно,

Да тонко бело полотно да белобархатно.

Да во первой раз вышивала светел месяц со лунами;

Да светел месяц со лунами, со частыми со звездами;

Да во второй раз вышивала красно солнце с маревами,

Да красно солнце с маревами, со теплыми облаками;

Да во третьей раз вышивала сыри боры со лесами,

Да сыри боры со лесами, со рыскучими зверями;

Да во четвертьй раз вышивала сине море со волнами,

Да сине море со волнами, со черными кораблями...

Да что й во пятых вышивала божю церковь с образами,
}

Да божю церковь с образами, со чудными со крестами.” (Эремина 1978: 55)

За разлику од везиљиног удела у постању света, лепота девојка из српске лирике користи нарочит материјал док подиже - свети храм (Караџић 1975: 234; Геземан 1925: $42^{\circ}$ ). Сакрална природа стварања и девичанске творачке моћи само се реализују на више начина, али им је исходиште истоветно. 
„На ђевојци кошуљица, Врх кошуље доламица, На глави јој окружница, На ногама папучице, Цв' јећем косу наресила, Пао ђердан по прсима" (Караџић 1973: 106º).

Чак и ако се догоди да девојачки атрибути сачувају нешто из митске подлоге, ти детаљи постају само декоративни чланови дескрипције, евентуално блиски метафори. Пастирица-преља није детаљно описана, али поседује особене предмете:

„У руци јој шимширли вретенце,

За појасом од злата куђеља,

При куђељи свила граничаста" (Караџић 1898: 302º).

Али, она је по обележјима далеко од сунчевих сестрица, небеских невести и вилинских посестрима, већ је мала жанр-сцена само оквир сусрета са драгим.

Смртне и оностране лепотице нису погубне само за момке и младожење, већ је некада угрожен опстанак и самог змаја. Мада је варијанта забележена у склопу светковања Спасовдана ${ }^{22}$, девојка надмудри змаја-отмичара и од чежње за њом „Пуче змаје на камену” (Караџић 1975: 270). Да нису сачуване околности импровизације, ова варијанта не би припала засебној руковети, већ би попут других сличне тематике могла да се придружи варијацијама о љубама оностраних бића (Караџић 1975: 238, $239^{\circ}$ ). Обраде се, заправо, рачвају у два правца. Свадбена атмосфера представља супериорну невесту или се околности змајеве отмице приближавају моделима о девојци коју просе три просца и салећу тројица бећара. Они брзо одустају од својих намера, а похоту замењује страх, када чују из какве је девојка породице. Њен исказ може да укључи и извесну „рационализацију”:

${ }^{22}$ Вазнесење Господње или Спасовдан је велики, покретан хришћански празник, који „пада увек у четвртак, и то шести по Ускрсу”. На архаична исходишта, која одражавају прожимања култа плодности са култом мртвих, али и процесе прожимања паганских остатака са хришћанском религијом, указују прописи светковања и текстови појединих варијаната. Од давнина је ово „пролећни празник сточара и земљорадника”, док су особите и спасовске задушнице. Веровало се да је тада могуће видети мртве, те су породице са понудама, после поноћи одлазиле на гробља, одакле се враћало „у свитање, а пре изгрева сунца” (Недељковић 1990: 226-229). 
„Ја сам кћерца цара честитога,

А сестрица паше босанскога,

Вјерна љуба змаја огњенога" (Караџић 1975: 239²).

Али, ову бледу (квази)историзацију неутралише завршна формула, колико год да се поређење, засновано на паралелизму, приближава и структури метафоре:

„Пак пролеће преко равна поља,

Као зв’језда преко ведра неба".

Исход сусрета на води истоветан је и при варирању порекла, при чему се име епског јунака изразитије апсорбује и готово неутралише у митолошким обрисима:

„Ја сам сеја змај-огњена Вука,

А љубовца огњевита змаја" (Караџић 1898/V: 250%).

По особинама које се подразумевају и приписују овако означеној лирској јунакињи, и она је сама огњевита. Сведено описана, у покрету, није мање опасна од крвних сродника или мужа:

„Када ходи, како ветар веје;

Кад говори како сабљом сече" (Караџић 1975: 238).

Премда обавља послове у складу са патријархалном поделом мушких и женских задужења, огњевита жена се не устручава ни да своје клетве упути месецу. И то би се могло препознати као вид антипонашања својственог митолошком комплексу, јер се од овако описане силне женске главе разликују врлине гиздаве удаваче, танане невесте ${ }^{23}$ и кротке љубе.

Осим универзално распрострањених представа о вилама и њиховом амбивалентном односу према људима, у митолошким песмама посебан статус припада сунчевој сестри и сунчевој/месечевој вереници. Онострана природа сунчеве сестрице истакнута је именовањем, посредством лепоте и/или кроз испољавање њених моћи над надменим смртницима, какви су цар, његови улаци и војска. Исход контакта зависи првенствено од човеко-

${ }^{23}$ Примера ради, склад духовне и физичке лепоте, суптилност опхођења и задивљујући изглед красе младу Гојковицу (Караџић 1988: 26) или изабраницу Милића барјактара:

„...Кад говори ка’ да голуб гуче,

Кад се смије ка' да бисер сије,

Кад погледа, како соко сиви,

Кад се шеће као паунице;

Побратиме, сва ти је гиздава...” (Караџић 1988а: 78). 
вог опхођења према супериорној митској девици (Krnjević 1986: 129-131). Било да некакав цар насилно жели да освоји љубу или опседа чудесно здање на међи простора (и времена) земаљска сила остаје поражена.

И вила неимарка града од костију и градитељка храма поседују обележја Велике мајке, господарице рађања и умирања. У српском фолклору многоструке су реализације ових архаичних представа. Својства прародитељке, хранитељке и владарке тмине имају и невесте и виле, Богородица која награђује и кажњава, мати-крвница и вештица. Управо међу митолошким лирским песмама доминантни су рефлекси који би могли сведочити о „matrijarhalnom mitu u lunarnoj mitologiji” (Matić 1979: 89).

\section{4. Небески просци}

Персонификована небеска тела и природне појаве, уобичајени су ликови и у бајкама, мада им ту припада делокруг помоћника и/или дародавца (Prop 1982: 86-90). Међутим, Сунце, Месец, Даница и Преодница су главни јунаци митолошке лирике, често крвни сродници, а њихове породичне везе се такође успостављају по моделу патријархалне задруге. Када су старешине кућа, Сунце и Месец имају потомке - сунчевића и месечића (Караџић 1973/I: $105^{\circ}$ ), али су чешће женици лепоте девојке. Такав статус подразумева особиту хијерархију, по којој звезда Даница као Месечева сестра, бира снаху и дарује сватове.

Мотив о красној удавачи за чију руку се надмећу махом три јунака може бити стилизован према законитостима разних песничких врста (Krstić 1984: 256-258). У митолошком комплексу тежиште обраде је на самој свадби (Караџић 1973/I: 104; 1975: 230², 231) или су изразитије истакнути разлози с којих невестин род даје предност једном од просаца (Караџић 1973/I: $105^{\circ}$; 1975: 229 $) .{ }^{24}$ Мотивација је заснована на опажањима природних појава, али искључује постојану предност истог младожење. Младина породица не прихвата сунце - огњевито / „нагло и жестоко", страхујући да ће им спржити сестру. А, месец је пожељнији женик од сунца због аналогије са сложном, многољудном патријархалном задругом. У богатом дому њихова ће сестра имати:

,... својте доста -

Све звијезде за јетрве, реходницу другарицу, А даницу заовицу” (Караџић 1975: 229).

${ }^{24}$ Krstić 1984: 1, 4 (A 1, 1 Ženidba sunca; A 2, 1 Ženidba meseca). 
Правилност (и тумачење) месечевих мена, по другој варијанти, постаје највећа младожењина мана:

„Он се мења за годину дана

Пуно право до дванаест пута,

Дванајст пута сестра удовица" (Караџић 1973/I: 105).

Зато се као најбољи брачни сапутник бира трећи просац - муња, мада је овај атрибут врховног божанства најчешће испрошена месечева невеста.

Поред тога што су ривали као просци, сунце и месец се међусобно споpe, или се у другачије осмишљеним околностима осуђују њихове особине:

„Жарко сунце да би не гријало,

Или ти се умалили зраци, то не гријеш зими к'о и љети,

Како и ја од мрака до жарка" (Караџић 1898/V: 253)

„О месече, царев неверниче!

Зашто грејеш цару на вечеру,

Те не грејеш ајдуком у гору,

Да разделе благо дубровачко" (Караџић 1975: 238º).

По истом принципу су Даница и Преодница сестре, другарице или завађене стране:

„Две се звезде на небу скараше,

Преодница и звезда Даница.

Преодница Даници беседи:

Ој Данице, лена лежавкињо,

Ти прележа од вечер' до света,

Ја обиђо земљу и градове...” (Караџић 1975: 275º).

Ови стихови, додуше, као и чувени прекор који месец упућује Даници због тога што се три дана не појављује (Караџић 1988: 98²), само су врста експозиције, којом се из небеске перспективе коментаришу драматични догађаји међу људима. Односно, човеково кршење неписаних етичких правила ремети и угрожава чак и постојан ритам природних мена и циклуса.

Рефлекси соларног и лунарног култа у српској традицији су веома запретени, али на древна штовања указују изрази, магија речи и прописаних радњи које ваља чинити или нису пожељни. ${ }^{25}$ У митолошкој лирици, поред

${ }^{25}$ „Зашао па не изашао! Кажу да одговори сунце кад му ко рече да је зашло, а кад му се рече да је сјело, оно одговори: сјео па не устао! Него му ваља казати: смирило се, па онда и оно одговори: Смирио се и ти!" 
месечеве свадбе и надметања девојке са сунцем, поступак паралелизма можда указује пут ка изједначавању младог месеца са судбином „изједеног” овчара. ${ }^{26}$ Сличне аналогије успостављају се и међу загонеткама:

„Пуно поље оваца,

Међу њима рогат чобанин";

„Поље немерено,

овце небројене;

међу њима чобан рогоња" (Новаковић 1877: 128-129).

Особита значења слуте се и у варијанти, изван митолошке руковети, о удесу ткаље Јање (Караџић 1975: 668º). Она је брижна љуба, чији војно подједнако припада и представама о (некој) ратничкој групи и оностраним силма, а приближава се и месечевом ритму, јер „Дањом болује, ноћом војује” (Самарџија 2013: 251-254). Означена једним од женских послова, Јања је и сама вишеструко блиска демонском свету. У српској традицији предење, ткање и слични женски радови, ${ }^{27}$ као и предмети које жена том приликом користи, подвргнути су низу табу-прописа. Они су везани „,za periode u kretanju nebeskih tela (Sunce i Mesec), za određene sedmične dane (obično sreda i petak), za neke hrišćanske praznike (...) na primer Međudnevicu, za koje su, po mišljenju Veselina Čajkanovića vezani tragovi kultova nekadašnjih ženskih božanstava" (Bandić 1980: 330-331; 324). И ткаља из ове варијанте могла би се придружити нуминозним бићима. За разлику од мајке изједеног овчара, Јања није виновник умирања, али јесте саучесник смрти. Скривајући тајну „болног Ђурице”, Јања га непрекидно крепи и девет година враћа из мртвих, чиме утире пут нестанку свога рода. Плен њеног мужа из (неког) смртоносног похода приближава се (донекле) даровима, које у другачијем контексту прима особит орач. Јер, док су вранац, десница и девојачка коса докази породичне трагедије, ратар помоћу заслужених дарова оствартује (супротно) начело, пресудно за човеково битисање на овоме свету.

Слично се, тамним тоновима, маркира и присуство преље на нечистом месту. Опасност се надвија над девојку, тим пре што је вода иначе амбивалентан симбол митолошког и ритуално-магијског комплекса (Bandić 1980: 255-263). Оностраност простора појачава сликом бунара који припада вилама, а ти чиниоци су битни и за одређење девојке као -

„Здрав здрављаче! нов новљаче! Каже се поскочивши мало новоме мјесецу кад се први пут угледа. А ђекоји још изваде и новчану кесу, ако у њој доста новаца има, те је тресну према мјесецу. За то свакога мрзи с празном кесом нов мјесец угледати" (Караџић 1987: 1417, $1446^{\circ}$ ).

${ }^{26}$ О томе више: Латковић 1975: 178-180; Карановић 2010: 59-70.

${ }^{27}$ О томр више: Карановић - Пешикан-Љуштановић 1994: 9-24. 
преље, јер се њена знања придружују хтонским сферама. Распрострањена су, на пример, веровања помоћу којих се „тумаче” шаре на месецу. Између осталих „прилика”, тамо се разазнаје и једна девојка. Она је „обичавала у очи недјеље на мјесечини прести, пак ју у очи Младе недјеље привукао мјесец у себе, те ено је сад сједи у мјесецу и преде" (Чајкановић 1927: 510; 1994/5: 335-339).

Симболизација месеца укључује и представе о загробном свету, док је месец народ поштовао „као најмоћнијег владара ноћи, а врачаре, одајући се својим враџбинама с намером да донесу пропаст људима, призивале су га као савезника" (Чајкановић 1994/2: 398; 1994/5: 335). Није занемарљива ни атрибуција - рогат и рогоња, тим пре што се и та симболика среће међу варијанатама о просидби месечеве љубе. Њено боравиште или пут до њеног дома указује и на улогу просторних релација при лирским стилизацијама митолошких призора.

\section{5. У срцу бора и „нуглу” Петровог поља}

Сведене, тек назначене, (данас) понекад и недовољно јасне радње лирских песама смештене су на различито означеном, али суштински апстрактном простору. За разлику од епске локализације, лирика тек по изузетку укључује конкретне географске одреднице. Но, чак и тада, називи насеља, гора и река лако алтернирају. Евентуално, могу сигнализирати терен са којег запис (или певач) потиче, док неки топоними, хидроними, ороними итд. могу постати носиоци сложенијих значења. С друге стране, општи појмови, уз познавање (или наговештај) околности импровизације подразумевају да се опевани догађај одвија на отвореном (извор, поље, гора, врт, преко села, испред куће) или, ређе, затвореном простору (,око скриње невестине", за трпезом, у вајату, на чардаку). По том принципу се просторно ситуирање митолошких минијатура изводи директно (равно поље, грана облака) или се посредством ликова (небеска тела, орач, чобаница, преља).

Простор на којем се одвија Прва, света свадба подразумева се именовањем актера, док је вилин град подигнут „на грани од облака” или негде, на граници светова уз директна поређења са Цариградом. Змајев лет обухвата такође велико пространство наглашено формулом „с мора на Дунаво". Табуисане су вилинске горе, извори и бунари, вила се скрива и на јасену, уврх Велебита седи на камену и пева песме. Усред јаворове горе, именом цвета изједначене су вода и девојка. Паралелизам повезује поље са небесима, а од златних јабука, бачених „небу у висине” настају 
смртоносне муње. Смртник, само по изузетку може досегнути до оностраних предела, а тада су два света у складном односу или се међусобно угрожавају (Караџић 1975: 224을 $225^{\circ}$ ).

Најсложеније је ситуирање варијаната о прошеници Сунца и Месеца или момка који, милошћу Божијом, стиче чудесне атрибуте. Девојачки дом је особити град. Именован је као подводни свет - Дунав, што је изазивало и Вукову недоумицу (Караџић 1975: 229), а по сродној варијанти, изван митолошке руковети, младу мому скрива борова кора (Караџић 1975: $505^{\circ}$ ). Независно од жанровског обележја, за обе песме карактеристична је дводелна композиција, чији први и други сегмент нису чврсто узрочно-последично повезани.

Митска просидба изведена је по аналогији са свадбеним обичајима, тако што деветорица браће бира пожељнијег зета. Други запис, међу „љубавним и различним женским пјесмама" више одступа од патријархалних канона, уз наговештај могуће отмице. Девојка, међутим, упозорава младића на опасност:

„У мен има девет браће,

И толико братучеда,

Кад појашу вране коње,

А припашу бритке сабље,

Пак накриве вучикапе,

Страота је погледати,

А камо ли дочекати...” (Караџић 1975: 505º)

Застрашујући призор је формулисан и у једној коледарској песми, само што вила упозорава:

„Устај горе, млад војвода,

Отуд иде чудно чудо,

Чудно чудо невиђено,

Страота је погледати,

А камо ли дочекати...” (Караџић 1975: 192º)

По Вуковом мишљењу ово „није читава пјесма”, те је остала нејасна природа невиђеног чуда. Недоумице покреће и проналажење девојке у вегетативном „скровишту”. Обдарен златним роговима и сребрним парошчићима, младић пробада бор. Усред стабла, налази девојку, а она, откривена: „засија кано сунце”. Поред тога што је симболика јелена и бора веома богата, занимљиву аналогију успоставља једна слика, такође из коледарске руковети. Док стара мајка жури ка цркви: 
„Сусрете је Свети Петар

На јелену златорогу,

Златорогу и парогу” (Караџић 1975: 191º)

И младић чији лик (и моћи) преображавају рогови и светац на јелену, нарочито у контексту празника посвећеног новом календарском циклусу, треба да симболизују моћ и снагу, плодност и изобиље. Зато су рогови били обавезни реквизит при божићном и покладном маскирању (Толстој 2001: 27), док се њихов облик може повезати и са изгледом месеца током прве и последње мене. Остаће нејасно да ли је, можда, момак који у бору налази мому и сам месечев „двојник”. Невеста је, с друге стране, јасно упоређена са сунцем или по круни коју носи, а није занемарљива ни њена веза са вечно зеленим дрветом, као симболом плодности и космичке вертикале. Опасна браћа и братанци могли би бити учесници обредне поворке, али право значење и примарна функција стихова тешко се могу поуздано реконструисати. Вертикала универзума, често представљена стаблом, постаје вишеструко средиште светова. Прстенови - годови из срца и језгра бора скривају или чувају будућност невесте и космичког поретка, а управо месец као „прототип сваке идеје умирања и поновног рађања" (Бидерман 2004: 233) омогућава струјање биљних сокова и утиче на бујност „земаљског” света.

Оса света упоређена је често са стаблом, али осим бора и различитог високог дрвеће, исти смисао имају планина, кула, стуб, копље. Таква слика карактеристична је за песму која је остала међу Вуковим рукописима:

„Расла кита ракита

Насред поља Петрова;

Све је поље прекрила,

Једног нугла не могла.

У нуглу су три постеље,

На њим сједе три госпоје,

Свака себи синка рани,

Свака своме име дије:

Једном име жарко сунце, Другом име сјај-мјесече, Трећем име тиха киша Жарко сунце за сироте, Сјај-мјесече за путнике, Тиха киша за шеницу, А шеница за колаче, А колачи за ђевојке, А ђевојке за јунаке, 
А јунаци за господу,

А господа за правицу,

А правицу и Бог љуби” (Караџић 1973/I: 101).

Према Вуковим строгим критеријумима, ова варијанта није досегнула естетске вредности осталих песама одабраних за антологију. Ипак, запис илуструје више процеса, својствених не само трајању митолошке лирике, већ и целокупног српског усменог стваралаштва. Слика дрвета из иницијалне формуле није необична, јер се тако, са одговарајућом јаче или слабије истакнутом симболиком, иначе отварају лирске минијатуре. ${ }^{28}$ Међутим, колико год да „подсећа” на географске орониме, ${ }^{29}$ ово Петрово поље није ни конкретно, нити било које, већ се односи на небеске сфере и рајско насеље. Уосталом, при уређењу космоса и подели „блага” међу свецима, Свети Петар узима „И кључеве од небеског царства” (Караџић 1988: $1^{\circ}$ ). Још један сигнал појачава сакрализацију, односно митски потенцијал простора, и пре но што се уведу ликови. То је само стабло раките, на чије гране по веровањима српског народа „ђаволи не смеју (...) гранчице носе се на Цвети у цркву, а после се њима ките куће и штала ,да одврате од дома и марве свако зло"” (Чајкановић 1985: 203).

Висина и ширина бескраја ипак су омеђени „нугловима” од којих је један изузетан по призору три мајке са својом децом. Заправо, до тих стихова, када мајке дају имена својим чедима, песма би могла да се укључи и међу породичне идиле. Након именовања ликова постају очити процеси христијанизације древних представа и пројекција породичног живота на оностране светове. Персонификовање жарког сунца, сјај-мјесеца и тихе кише јесте кулминација митског призора, али је сврха саме варијанте избледела у времену њеног певања и бележења. Покушај да се „надокнади” изгубљени смисао уноси и извесну жанровску колебљивост. Сама појава није неуобичајена управо у усменој лирици. ${ }^{30}$ Али, призор из митских сфера - са Петровог поља није отворио путеве исказивању љубави између

28 Расла јабука Ранку пред двором;

Расла јела насред Сарајева;

Расло дрво бадемово, танко високо;

Расло дрво сред раја (Караџић $\left.1975: 108^{\circ}, 423^{\circ}, 438^{\circ}, 622^{\circ}, 209^{\circ}\right)$

${ }^{29}$ Бијело поље, Косово поље, Попово поље, Царево поље итд.

${ }^{30}$ На то је указао још Владан Недић, осветљавајући судбину појединих „текстова” обредних и обичајних врста, који су се могли током векова преобразити у љубавне песме: „Како је то ишло? Елементи љубавне лирике јављали су се најпре тихо, на самом крају песме. Затим су лагано захватали стихове испред себе. Разарајући све више старо ткиво они су продирали ка почетку песме. Временом песма која је некад била везана за обред постајала је чиста љубавна" (Недић 1977: 15) 
двоје младих, слављењу породичне идиле, обележавању аграрног календара и сл. На почетну секвенцу, која је могла имати и обредна исходишта, надовезао се каталог, док је поента добила дидактичну тенденцију, као млађи рефлекс хришћанског уздања у Бога и правду - међу људима.

\section{6. Пре но што је и Бог ходао по земљи}

Митолошкој лирици својствена је и особена конструкција формула времена. Сведене радње, описи, исповести и дијалози из „женских” песама махом се одвијају у садашњости, непосредној прошлости или слуте блиску будућност. Но, мада је садашње време усмене лирике затворено „сижеом и сижеом се исцрпљује”, истовремено располаже „способношћу ,поновљивости"”, тим пре што се односи „на ново време, време извођења” (Лихачов 1972: 267). Премда се ове категорије морају детаљније разматрати, временска перспектива „особито митологичких” лирских варијаната обликована је другачије, колико год се сам „текст” може изнова импровизовати. Јер, лирска „прича”, дескрипција, наративни и исповедни фрагменти митолошких песама постављени су у неку врсту темпоралног вакуума.

Оно што изгледа као да се догађа сада (Рано рани ђевојчица; Паде магла по Бојани, Радује се звијезда Данииа, Отуд лети јато соколова итд.) обухвата, заправо, прошлост. Догађај на који се односе лирски искази (Прођох гору...; Град градила...; Свилу прело...; Фалила се...) може подразумевати и (неко) пређашње, протекло време. Тај интервал није прецизиран, али баш зато се ствара утисак да су далекосежне последице радње, стања, разговора. Опеван је исход процеса - нпр. подизања вилинских градова, ратареве одане службе или тренутак - небеска просидба и свадба, подела поклона званицама, надметање девојке са вилом или сунцем итд. Али, и дужи и краћи „интервали” детерминишу космички (и друштвени) поредак, при чему се управо тим чином релативизују релације између ритма природе и конвенција одређене заједнице. „У народној култури (обредности, веровањима, фолклору) модел људског живота се удева у модел природе, целокупног света који га окружује, сакрализујући и годишњи круг времена (митолошког календара), и вегетативни циклус (,житије’ биљних култура) и производну људску делатност (ткаштво, грнчарство и сл) претварајући природу у културу" (Толстој 1995: 301).

Аграрни календар се постојано повезује са именима хришћанских светаца. Њихови атрибути подразумевају хармоничан поредак, док склад започиње након небеске свадбе и даривања сватова. По стихованим легендама Бог дарује светитеље пошто је кажњено човечанство огрезло у греху. 
Нови циклус започиње увођењем поретка по окончаном хаосу, који није прапочетак, већ поремећај изазван моралним суновратом људског рода. Процеси христијанизације слабије су испољени у једној варијанти, мада је паралелизмом из иницијалне формуле успостављена аналогија између морског и рајског пространства: „Широко море како рај” (Караџић 1973: $106^{\circ}$ ). Пажња се затим усмерава на лађу, њеног капетана и његову танану, белу кошуљу, која изазива чуђење посаде:

„На Јова танка кошуља,

Тања је пера макова,

А бјеља лијера од горе”.

Исповест Јове капетана „помера” смисао песме ка митским сферама, уз евоцирање свадбеног ритуала и карактеризације лирског јунака као оностраног бића:
„Кад вила сина жењаше
За кума мене стављаше, Ја вили прстен даровах, У прстен небо и облак,
А вила мене кошуљу!"

Тако се на (неком) почетку стварања светова особитим даром и уздарјем регулише свеопшти поредак, а вила - женикова мајка добија власт над небеским сводом. ${ }^{31}$

Иако нису многобројне, поједине варијанте се по околностима прастварања приближавају етиолошким предањима и легендама. Једну Вук придружује посленичким песмама „које се пјевају на прелу”. Док напаса јелене, анонимна пастирица умире под необичним околностима, а из њеног тела расте брекиња. Чобани је посеку, од ње начине свирале и:

„У свирале говоре:

Преди, момо, дарове.” (Караџић 1975: 244)

Још је сличнија особеностима етиолошких предања стихована легенда, певана, по Вуковом сведочењу и распореду грађе - „уз часни пост”. Други сегмент односи се на разлоге с којих јасика нема рода, а непрекидно

31 Значења богате симболике прстена слично се реализују и у стиховима једне додолске песме. Док обредна поворка иде преко села, упоређена је са облацима, а:

,...Из облака прстен паде,

Ој додо ле,

Мој божоле!

Ујагми га коловођа...” (Караџић 1975: 188). 
трепери „Усред љета и без вјетра!” (Караџић 1975: 197). Занимљиво је да се оба, суштински супротна „догађаја”, такође приказују уз доминацију женског начела, док се „збивање” из прошлости непрекидно евоцира песмом пастира, постојањем брекиње и удесом јасике.

Време радње и/или слике приближава целокупну митолошку лирику обредној манифестацији и, истовремено, указује на разлике између лирских подврста. Ритуална пракса има исходиште у неком (недокучивом) правремену или предвремену, које није нужно засебно објашњавати. Оно се подразумева сваки пут када се кроз ритам природних мена или животни пут човека понављ $а$ иста ситуација. Та поновљивост обредно-магијског контекста не испољава се експлицитно кроз митолошки лирски текст. Једном установљен поредак не да се изменити, само што и тако затворено време оставља трајне - вечне последице. Обредно време је додатно сакрализовано тенденцијом ритуално-магијске праксе и циљем сложене инсценације. „Митолошко” време не мора имати такав статус или је тај тип прагматичности постепено неутралисан и више се не препознаје. С друге стране, особитост митског времена подразумева да „sadašnje stanje sveta - reljef, nebeska tela, vrste životinja i biljaka, način života, socijalne grupacije i religijske ustanove, svi prirodni predmeti - predstavljaju posledice događaja iz davno prošlog vremena.” (Meletinski b. g: 175). Темпоралне категорије митолошке лирике потврђују да „ороzicija sakralnog i profanog vremena nije apsolutna. U krajnje statičnoj predstavi mitskog razdoblja postoje crte sinkretičkog shvatanja o vremenu kao sferi uzročnosti (...), kao oblasti elementarnog suprotstavljanja ranije i sada, prošlosti i sadašnjosti" (Meletinski b. g: 180). Извесна флексибилност односа према прапочецима укључује и више етапа кроз које се мењао читав комплекс културе. Уз све то, обред је особена реактуализација „догађаја” из изворног, светог Времена, „koje ne ,teče' (...) a sačinjeno je od večne sadašnjosti koja se može beskrajno ponavljati” (Elijade 2004: 65). Захваљујући таквом парадоксу (који укључује и десакрализацију) било је могуће да се поједине слике и радње, сродне митолошком комплексу, преобликују, било да су подвргнуте христијанизацији или се „приближавају” обредним, обичајним, посленичким, породичним и, нарочито, љубавним лирским песмама.

\section{7. „Границе” усмених врста}

Синкретизам, као обележје древних култура, одржао се у усменом стваралаштву првенствено кроз спој више уметности или некадашњих рудиментарних зачетака уметности. „Тако се лирска народна песма увек пева, 
често у колу, уз плес; код неких лирских песама, краљичких, додолских, прпорушких и сличних, имамо у споју и глуму у примитивном облику” (Латковић 1975: 10). Природа непосредне импровизације, симултаност стваралачког чина и рецепције дела, такође почивају на видовима синкретичности. Заправо, у целокупној народној књижевности синкретизам се испољава на више начина, јер подразумева и преплете хронолошки различитих слојева баштине (религијски, или „унутрашњи синкретизам”32), резултате контаката са културама других народа и динамична преплитања усмених родова и врста. ${ }^{33}$

Облици усменог стваралаштва изградили су током векова сопствене поетичке законитости. Њихове границе су истовремено порозне, о чему упечатљиво сведочи већ Вуково издвајање песама и приповедака „на међи”. Унутар истог поетичког „микросистема”, какав представљају лирске „религиозне” подврсте и при сагледавању њихових веза са осталим песничким и прозним формама уочавају се сложени процеси, који су се одвијали у целокупној традицији. Осим преплета паганске и хришћанске религије, изразита је и жанровска флексибилност, док на „статус” и смисао слике - формуле утиче више чинилаца. Упркос стабилности, значења осцилирају у широком распону од фантастичних призора, преко ритуално-магијске „мотивације” до фигуративног плана израза, склопа и функције стилских фигура. Делимично сличне или подударне „конструкције” са лакоћом се „премештају” из једне врсте у другу. Зато је (данас) веома тешко да се реконструишу исходиште и (првобитна) намена појединих варијаната, нарочито када су остале непознате околности импровизације. Такав „случај” илуструју митске „секвенце” међу „љубавним и другим различним женским пјесмама" Вукове збирке; дублети коледарских и божићних песама; тематска сродност митолошке лирике са песмама „онако побожним"34, али и са легендама у стиху и прози, подврстама предања,

${ }^{32}$ Како сматра В. Чајкановић: „...не треба, наиме, заборавити да су се у току историје многе ствари мењале, нарочито онда када се наш народ раширио, и на тај начин дошао у додир са другим народима и када су поједини његови делови почели живети другим начином живота и у промењеним културним приликама (...) Последица тога била је известан унутрашњи синкретизам схватања и религијске праксе, при чему није било од значаја што ће ново често противречити староме" (Чајкановић 1994/5: 55-56).

${ }^{33} \mathrm{He}$ сме се заборавити ни релативно позно бележење текстова, при чему су и сакупљачи и издавачи умотворина често интервенисали у тексту забележене варијанте.

${ }^{34}$ Тако је Вук издвојио девету руковети првог бечког тома Српских народних пјесама, где је штампао само пет песама: Критење Христово; Опет критење Христово; Неблагодарни син; Неблагодарни синови; Бећар Мара и Перо Бугарин $\left(202^{\circ}-206^{\circ}\right)$. Знатно је више записа

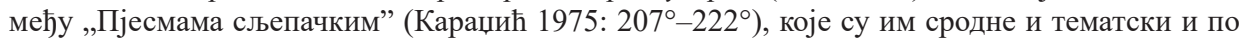
дидактичној тенденцији. Обиље грађе из које је састављен избор, потврђује државно издање, уз 
формулацијама загонетки и дела пословица, појединим сегментима бајки и разним примерима прожимања прозних облика.

Ликови, тематика, поступци стилизације, ритмичка организација „текста”, самостално издвојени нису структурно-семантички „пресудни” сигнали који би поуздано указали на жанровску специфичност митолошке лирике. Јунаци и мотиви припадају општем фонду традиције. Варијанте се разликују од лирско-епских обрада, јер су „краће”, како би рекао Вук. Осим тога, митолошко-хришћанске песме „на међи”, с почетка друге књиге Вукових Српских народних пјесама, испеване су у асиметричном десетерцу. Митолошка руковет је на том, формалном плану, особена по разноврснијој версификацији, ${ }^{35}$ али је то иначе карактеристично за све

важну напомену: „Ове се пјесме обично не пјевају, него их понајвише жене и дјевојке на сијелу казују, особито уз четворо поста годишњијех” (Караџић 1989: 155. VII „Пјесме побожне”: $217^{\circ}-249^{\circ}$ ). Ж. Младеновић и В. Недић су објавили још једну „онако побожну” варијанту: Караџић: $97^{\circ}$, Hajвећи гријеси, а засебно су издвојили „Пјесме које се пјевају уз часни пост и на Ђурђевдан” $\left(92^{\circ}-96^{\circ}\right)$ и три „Пјесме сљепачке” $\left(98^{\circ}-100^{\circ}\right)$.

${ }^{35}$ Наведене су само варијанте које су Вук и приређивачи његових рукописа експлицитно уврстили међу митолошке лирске песме:

\begin{tabular}{|c|c|c|}
\hline Стих & Пример & Извор \\
\hline шестерац & Шеђела је | Анђе & Караџић 1973: $107^{\circ}$ \\
\hline седмерац & Престан' | престан' | кишице & Караџић 1973: $109^{\circ}$ \\
\hline \multirow[t]{10}{*}{ осмерац } & Ај, ђевојко | душо моја & Караџић 1975: $235^{\circ}$ \\
\hline & Град градила | б'јела вила & Караџић 1975: $226^{\circ}$ \\
\hline & Ђевојчице | наранчице & Караџић 1973: $108^{\circ}$ \\
\hline & Ој орачу! | млад орачу & Караџић 1975: $236^{\circ}$ \\
\hline & \begin{tabular}{|l|l|} 
Ocy ce $\mid$ небо | звездама \\
\end{tabular} & Караџић 1975: $237^{\circ}$ \\
\hline & \begin{tabular}{|l|l|} 
Паде магла $\mid$ на Бојани \\
\end{tabular} & Караџић 1975: 229 \\
\hline & \begin{tabular}{|l|l|} 
Прођох гору прођох другу \\
\end{tabular} & Караџић 1975: $225^{\circ}$ \\
\hline & Рано рани | ђевојчица & Караџић 1975: $224^{\circ}$ \\
\hline & С ону страну | Цариграда & Караџић 1898: $254^{\circ}$ \\
\hline & \begin{tabular}{|l|} 
Широко море | како рај \\
\end{tabular} & Караџић 1973: $106^{\circ}$ \\
\hline \multirow[t]{11}{*}{ десетерац } & Ђевојка је | уз горицу стала & Караџић 1973: $102^{\circ}$ \\
\hline & Ђевојка се | сунцем опкладила & Караџић 1973: $103^{\circ}$ \\
\hline & Запросио | Несијевић Јово & Караџић 1898: $255^{\circ}$ \\
\hline & Змај пролеће | с мора на Дунаво & Караџић 1975: 239 \\
\hline & Змај полеће | с мора на Дунаво & Караџић 1898: $250^{\circ}$ \\
\hline & Извирала | студена водица & Караџић 1975: $232^{\circ}$ \\
\hline & Кладила се $\mid$ вила и ђевојка & Караџић 1898: $251^{\circ}$ \\
\hline & \begin{tabular}{|l|} 
Кликовала | пребијела вила \\
\end{tabular} & Караџић 1898: $256^{\circ}$ \\
\hline & Коњ зеленко | росну траву пасе & Караџић 1898: $253^{\circ}$ \\
\hline & Мили Боже | чуда големога & Караџић 1973: $104^{\circ}$ \\
\hline & Отуд лети | јато соколова & Караџић 1975: 238 \\
\hline
\end{tabular}


лирске врсте. Од њих се не разликују ни композициони модели „особито митологичких пјесама”, остварени „у богатом спектру (...) монолог, дијалог, приповедна форма сједињена с монологом или дијалогом, сразмерно честа композициона схема описно-приповедног обликовања лирске ситуације, потом и сложеније посебне форме као што су монолог у монологу и дијалози у оквиру једног монолога" (Крњевић 1988: 122).

Заступљеност формула и фигура још мање може послужити као структурно полазиште при разликовању митолошких песама од осталих, јер је изражајни фонд формулативности наджанровске природе. Сложеност митских слика и представа одлично илуструје „текст” једне песме, заправо, сегмент меморате ${ }^{36}$, коју је Вук битно преобликовао у функцији напомене:

„Да зна женска глава,

Што ј' одољан трава,

Свагда би га брала,

У пас ушивала,

Уза се носила (...)

У Вуковару један старац родом из Босне с Тромеђе приповиједао ми je, како је у Велебиту г л е д а о вилу гдје сједи на камену и ове пјесмице пјева. Ја сам ове пјесмице слушао и од других људи и жена, само што ме нико други није увјеравао, да их је он од виле чуо" (Караџић 1975: 171, 223).

Чак и овако измењен, сачуван контекст импровизације „одређује” жанровску припадност записа. Да тих података нема, Вилина песма могла се наћи међу „различним женским пјесмама”, као вид стихованих савета. C друге стране и упркос Вуковој дистанци према поузданом казивању ,једног старца”, посредно се потврђују опасности које вребају мушкарце

\begin{tabular}{|c|c|c|}
\hline & 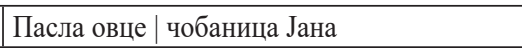 & Караџић 1898: $257^{\circ}$ \\
\hline & Радује се | звијезда Даница & Караџић 1975: $231^{\circ}$ \\
\hline & Свилу прело | злато материно & Караџић 1975: $228^{\circ}$ \\
\hline & Тамо кажу | гору јаворову & Караџић 1975: $233^{\circ}$ \\
\hline & Три су цвета | у гори цветала & Караџић 1973: 105 \\
\hline & \begin{tabular}{|l|l|} 
Фалила се | звијезда Даница \\
\end{tabular} & Караџић 1975: $230^{\circ}$ \\
\hline & Фалила се | лепота девојка & Караџић 1975: $234^{\circ}$ \\
\hline једанаестерац & Киша паде $\mid$ медна роса $\mid$ у пољу & Караџић 1975: $227^{\circ}$ \\
\hline тринаестерац & Град градила | б’јела вила | као Цариград & Караџић 1975: $252^{\circ}$ \\
\hline
\end{tabular}

${ }^{36}$ Ова форма демонолошких предања стилизована је као казивање „о ličnim doživljajima, sopstvenim sećanjima, koje postaje deo tradicije i počinje se prenositi kao predanje, pošto ga usvoje i drugi kazivači, interpretirajući ga uvek kao svoj doživljaj" (Pešić - Milošević-Đorđević 1984: 156). О проблематичној дистинкцији између меморате и причања о животу в: Делић 2019: 363-372. 
од оностраних моћи жена из оба света. Јер, не само виле, већ и њихове посестриме, биљарице, врачаре, бајалице, поседују тајна знања. Користећи свет природе - тајновита својства воде и земље, флоре и фауне, такве жене штите себе и своје, некад исцељују, а најчешће управљају туђим животима и угрожавају судбине других људи.

У обиљу примера чија структурно-семантичка својства испољавају сложене процесе усмених стилизација једна песма, сврстана међу „побожне”, открива - природу варијантности, амалгаме религијских слојева и флексибилност усмених облика:

„Цар небесни кад жењаше сунце,

Светитеље у сватове зваше:

Старог свата Петра усред љета,

Првијенца громовник' Илију,

А за кума Крститељ’ Јована, Два девера два Божја анђела, Барјактара у прољеће Ђурђа, А чауша Светога Николу, Пратиоияа Светог Аранђела. Отидоше свеци по ђевојку, У ђевојке светодуе Јање, Лијепо их тамо дочекали, И лијепим даром даровали, Сваком свецу, шта је за којега: Илиј' даше муње и громове, Светом Петру у снопе шенииу, А Јовану крсте и иконе, Анђелима кључе од небеса, Барјактару светитељу Ђурђу Дароваше ив'јеће и прољеће, А Николи по мору бродове, Аранђелу све ришћанске душе. Отолен се свати подигоше, И на небу трудни починуше, Најтруднија светодуа јања. Сјела Јања куму уз кољено, На кума је наслонила главу; Кад освану и ограну сунце, Сунце сјану, те уграби Јању.” (Караџић 1898: 217º)

Уз два (двострука) каталога - сватовских званица, њихових улога и атрибута, односно добијених дарова, занимљив је оквир ове обраде, у којем је запретена природа саме невесте. Наиме, удавача - светодуа Јања 
је по „тумачењу” певачице „која је ову пјесму казивала (...) Света Ана, мајка Свете Богородице" (Караџић 1898: 155). По свему судећи, млада и окупљени свеци заменили су нека старија божанства, док се боље очувала извесна архаична небеска хијерархија. Елементи матријархата уступили су место другачијем поретку, јер не жени брата звезда Даница, већ свадбу иницира „цар небесни”. То не мора бити ни хришћански старозаветни Бог, тим пре што је замагљена веза између врховног божанства и младожење. Сунце је, у тако постављеној обредно-митској сценографији најпре тек послушан, пасиван женик, који нема удела при избору невесте и реализацији свадбе. Таква „позиција” младожење не одступа од уобичајених обредних конвенција и патријархалних назора. Међутим, карактеризација се битно мења у завршници свадбе. На дужину свадбеног путовања и пировања указује умор учесника, док се њихов - небески сан подудара са тамним периодом дневно-ноћног циклуса. Спокој уснулих светаца, анђела и невесте - налик смрти, преокреће смена светлости и мрака: „Кад освану и ограну сунце”. И, мада је читава светковина организована као регуларна свадба, очито благословена вољом небеског владара и присутних гостију, младожења поступа неочекивано, готово нелогично: „Сунце сјану, те уграби Јању”. Поента би се, заправо, могла посматрати и као један вид манифестације инерције митеме.

Отмица љубе, чији ће пород бити мати будућег сина Божијег и спаситеља човечанства, најсличнија је митским заплетима о уграбљеним девицама и женама, које на силу, превару или уз њихов пристанак обљуби пагански бог. Тако Зевс отима Еуропу и Егину, Бореј Оритију, Тезеј Хелену, Ида Марпесу, али је свакако најважније Хадово отимање Персефоне (Просерпине, Коре), која у аграрним митско-ритуалним комплексима „spaja funkciju htonske gospodarice carstva mrtvih i boginje plodnosti" (Meletinski b.g: 223). Околности отмице - као функције (у морфолошком значењу), ${ }^{37}$ посматрано дијахроно и синхроно, показују да је митски комплекс истовремено постојан и подложан трансформацијама.

Чин отимања и жртва - плен (девојка/жена) су стабилни, наджанровски елементи фабуле. За жанровска нијансирања пресудно је коме припада улога отмичара. Сунце, често означено епитетима жарко и огњено, лако алтернира са огњевитим - змајем (спасовске песме; бајке), док је хтонска

${ }^{37}$ Разматрајући „stalne i promenljive veličine” у структури бајке, В. Проп је закључио да се мењају „nazivi (i s njima atributi) likova, ali se ne menjaju njihove radnje ili funkcije (...) Za proučavanje bajke važno pitanje je šta čine likovi u bajci, dok su pitanja ko čini i kako čini - samo pitanja za dopunska proučavanja" (Prop 1982: 27). У том смислу функција - радња (kakvu npr. predstavqa otmica) може се посматрати не само у поетичким оквирима бајке, већ је полазиште могуће применити и на остале наративне форме. 
компонента доминантна када девојку уграби - епски Арапин. Међутим, значење се „приклања” опречним начелима, односно глорификацији живота или упозорењу од смртних опасности. Да би прича (п)остала јасна, удаљавања од исконских митско-обредних исходишта захтевају увођење новог делокруга, при чему се улога спасиоца нарочито усклађује са поетичким системима, док се елементи иницијације и/или аграрно-календарски комплекс „povlači u pozadinu” (Meletinski b.g: 223).

Због свега тога „колебање око одређивања и разграничавања тзв. спољашње и унутарње форме лирске народне песме (...) није ствар површности или несналажења, већ је резултат саме суштине и природе усмених књижевних форми, подложних сталном кретању и мењању" (Крњевић 1988: 137-138). Сви структурно-семантички чиниоци делују здружено при досезању до значења „текста”. На том путу равноправни, некада пресудни удео имају околности импровизације, циљеви и намене певања, који се не могу занемарити, премда су временом уступили место препознавању естетских домета стилизације.

\section{ЛИТЕРАТУРА}

Bandić 1980. D. Bandić, Tabu u tradicionalnoj kulturi Srba. Beograd: BIGZ. Бандић 1990. Д. Бандић, Царство земаљско и изарство небеско. Београд: БИГЗ.

Бандић 2010. Д. Бандић, Народно православље. Београд: БИГЗ.

Bošković-Stulli 1978. M. Bošković-Stulli - D. Zečević, Divna, Usmena i pučka književnost. Zagreb: Liber - Mladost.

Влаховић 1987. П. Влаховић, Писции наше етнологије и антропологије. Београд: Филозофски факултет.

Вукмановић 2020. А. Вукмановић, У трагағу за извир-водом. Нови Сад: Академска књига.

Gavazzi 1921. Mi. Gavazzi, Uz šestu knjigu narodnih pjesama zbornika Matice hrvatske. Nastavni vjesnik, XXIX (1921): 337-345.

Делић 2019. Л. Делић, Змија, а српска. Концептуализащија у усменом фолклору. Андрићград - Вишеград: Андрићев институт.

Детелић 1992. М. Детелић, Митски простор и епика. Београд: САНУ.

Детелић 1996. М. Детелић, Од мита до формуле. Мит. Зборник радова, ур. Т. Бекић. Нови Сад: Филозофски факултет: 13-20.

Ђорђевић 1939. Т. Р. Ђорђевић, Белешке о намој народној поезији. Београд: Државна штампарија Краљевине Југославије. 
Ђорђевић 1958. Т. Р. Ђорђевић, Природа у веровању и предању нашег народа, 1-2. Београд: Српски етнографски зборник, 71-72 (1958); Београд: СКЗ, 2021.²

Ђорђевић 1983. Т. Р. Ђорђевић, Из Србије кнеза Милоша, пр. Б. Јовановић, Београд: Просвета.

Ђорђевић 1984. Т. Р. Ђорђевић, Наш народни живот, 1-4, пр. Н. Љубинковић, Београд: Просвета.

Ђорђевић 1985. Т. Р. Ђорђевић, Зле очи у веровағима Јужних Словена, пог. Љ. Раденковић. Београд: Просвета.

Ђорђевић 1989. Т. Р. Ђорђевић, Вештица и вила у нашем народном веровағу и предағу, пр. Н. Поповић-Перишић, Београд: Народна библиотека Србије - Дечје новине.

Ђорђевић 1990. Т. Р. Ђорђевић, Деца у веровањима и обичајима намега народа. Београд - Ниш: Идеа - Просвета.

Ђорђевић 2002. Т. Р. Ђорђевић, Животни круг - рођење, свадба и смрт у веровањима и обичајима наег народа. Ниш: Просвета.

Ђурић 1954. В. Ђурић, Постанак и развој народне књижевности. Београд: Знање.

Ђурић 1923. М. Ђурић, Поводом металогике у народној песми. Миcao, XII/5-6 (1923): 976-995.

Ђурић 1925. М. Ђурић, Мит о сунчевој сестри или познато и непознато у митској философији. Београд: М. Ђурић.

Ђуровић 1931. Д. Ђуровић, Народне умотворине. Београд: Геца Кон.

Elijade 2004. M. Elijade, Sveto i profano. Priroda religije. Beograd: Plavo slovo.

Зечевић 1981. С. Зечевић, Митска бића српских предаға. Београд: Вук Караџић - Етнографски музеј.

Зечевић 1982. С. Зечевић, Култ мртвих код Срба. Београд: Вук Караџић - Етнографски музеј.

Jagić 1867. V. Jagić, Historija književnosti naroda hrvatskoga i srpskoga, I. Zagreb: Štamparija Dragutina Albrechta.

Эремина 1978. В. И. Эремина, Поэтический строй русской народной лирики. Ленинград: Наука.

Јовановић 1937. В. Јовановић, Српске народне песме. Антологија (пето издање). Београд: Задруга професорског друштва.

Карановић 1996. 3. Карановић, Антологија српске лирске усмене nоезије. Нови Сад: Светови.

Карановић 2010. 3. Карановић, Небеска невеста. Београд: Друштво за српски језик и књижевност Србије. 
Карановић 2019. 3. Карановић, Вуков речник и српска култура. Књига о заборављеним световима. Београд - Пожега: Вукова задужбина - Издавачка радионица свитак.

Карановић 2021. 3. Карановић, Прочула се убава девојка. Лепота и формуле лепоте у српским народним песмама из теренске збирке са Тимока. Куле и градови. In тетогіат Мирјана Детелић, ур. Л. Делић-С. Самарџија. Београд: Балканолошки институт САНУ - Удружење фолклориста Срибије: 480-497.

Карановић, Пешикан-Љуштановић 1994. 3. Карановић - Љ. Пешикан-Љуштановић, Послови и дани српске песничке традиције. Нови Сад: Светови.

Караџић 1898. В. С. Караџић, Српске народне пјесме, V, Државно издање, пр. Љ. Стојановић. Београд: Штампарија Краљевине Србије.

Караџић 1966. В. С. Караџић, Српски рјечник 1818. Сабрана дела В. С. Караџића, књ. II, пр. П. Ивић, Београд: Просвета.

Караџић 1969. В. С. Караџић, Даница 1826 - 1827 - 1828 - 1829 - 1834. Сабрана дела В. С. Караџића, књ. VIII, пр. М. Павић, Београд: Просвета.

Караџић 1972. В. С. Караџић, Етнографски списи. Сабрана дела В. С. Караџића, књ. XVII, пр. М. С. Филиповић, Београд: Просвета.

Караџић 1973. В. С. Караџић, Српске народне пјесме из необјављених рукописа Вука Караиића, I, пр. Ж. Младеновић Ж. -В. Недић. Београд: САНУ.

Караџић 1975. В. С. Караџић, Српске народне пјесме, I, Сабрана дела В. С. Караџића, IV, пр. В. Недић. Београд: Просвета.

Караџић 1986. В. С. Караџић, Српски рјечник 1852, I-II. Сабрана дела В. С. Караџића, књ. ХI/1-2, пр. Ј. Кашић, Београд: Просвета.

Караџић 1987. В. С. Караџић, Српске народне пословице. Сабрана дела В. С. Караџића, књ. IX, пр. М. Пантић, Београд: Просвета.

Караџић 1988. В. С. Караџић, Српске народне пјесме, II, СД, V, пр. Р. Пешић. Београд: Просвета.

Караџић 1988а. В. С. Караџић, Сриске народне пјесме, III, СД VI. пр. Р. Самарџић. Београд: Просвета.

Ковачевић 2001. И. Ковачевић, Историја српске етнологије, 1-2, Београд: Српски генеалошки центар.

Koljević 1982. S. Koljević, Ka poetici narodnog pesništva. Beograd: Prosveta.

Krnjević 1986. H. Krnjević, Lirski istočnici. Iz istorije i poetike lirske narodne poezije. Beograd - Priština: BIGZ - Jedinstvo. 
Крњевић 1988. Х. Крњевић, Скица за видове композиције лирске народне песме. Поетика српске књижевности, ур. Н. Петковић. Београд: Институт за књижевност и уметност: 117-139.

Krstić 1984. B. Krstić, Indeks motiva narodnih pesama balkanskih Slovena. Beograd: SANU.

M. K. 1873. M. K. Sunce u naših bajoslovnih ostatcih. Vienac, V (1873): 410-416, 427-432, 442-445, 459-462.

Латковић 1975. В. Латковић, Народна књижевност. Београд: Научна књига.

Leže 1984. L. Leže, Slovenska mitologija, Beograd: Grafos.

Лихачов 1972. Д. С. Лихачов, Поетика старе руске књижевности. Београд: СКЗ.

Лома 2002. А. Лома, Пракосово. Словенски и индоевропски корени српске епике. Београд: САНУ.

Љубинковић 2014. Н. Љубинковић, Наши далеки прещи. Етномитолошке студије. Београд: СКЗ.

Matić 1979. V. Matić, Psihoanaliza mitske prošlosti. Beograd: Prosveta.

Матић б.г. С. Матић, Антологија народних песама са прегледом народне књижевности. Београд: Народна просвета.

Meletinski b. g. E. M. Meletinski, Poetika mita. Beograd: Nolit.

Милићевић 1984. М. Ђ. Милићевић, Живот Срба сељака, пог. И. Ковачевић. Београд: Просвета.

Милошевић Ђорђевић 1980. Н. Милошевић Ђорђевић, Теорије о настанку народних приповедака у нашој науци 19. века, Зборник реферата и саопштења са међународних научних састанака слависта у Вукове дане, 9 (1980). Београд: МСЦ: 495-500.

Milošević-Đorđević 1984. N. Milošević-Đorđević, Mitološke pesme. Pešić, R - Milošević-Đorđević, N. Narodna književnost. Beograd: Vuk Karadžić: 163.

Милошевић Ђорђевић 2000. Н. Милошевић Ђорђевић, Од бајке до изреке. Београд: Друштво за српски језик и књижевност Србије, 2000.

Мит. Зборник радова, ур. Т. Бекић. Нови Сад: Филозофски факултет, 1996.

Мојашевић 1950. М. Мојашевић, Српска народна приповетка у немачким преводима од Грима и Вука до Лескина (1815-1915). Београд: Научна књига.

Недељковић 1990. М. Недељковић, Годишьи обичаји у Срба. Београд: Вук Караџић.

Недић 1977. В. Недић, Антологија народне лирске поезије. Београд: СКЗ.

Nedić 1985. V. Nedić, Mitološke pesme. Rečnik književnih termina. Beograd: Nolit, 1985: 441. 
Новаковић 1977. С. Новаковић, Српске народне загонетке. Београд - Панчево: Књижарница В. Валожића - Књижарница браће Јовановић.

Nodilo 1981. N. Nodilo, Stara vjera Srba i Hrvata. Split: Logos.

Павловић 1982. М. Павловић, Антологија лирске народне поезије, Београд: Вук Караџић.

Петковић 2007. Н. Петковић, Словенске пчеле у Грачаници: огледи и чланци о српској књижевности и култури, пр. Д. Хамовић, Београд: Завод за уџбенике.

Pešić, Milošević-Đorđević 1984. R. Pešić - N. Milošević-Đorđević, Narodna književnost. Beograd: Vuk Karadžić.

Поповић 1983. М. Поповић, Памтивек: Српски рјечник В. С. Каращића, Београд: Завод за уџбенике.

Поповић 1931. П. Поповић, Преглед српске књижевности (девето издање). Београд: Геца Кон.

Продановић 1938. Ј. Продановић, Антологија народне поезије. Београд: Геца Кон.

Prop 1982. V. Prop, Morfologija bajke. Beograd: Prosveta.

Раденковић 2015. Љ. Раденковић, Значај дела Вука Караџића за изучавање српске митологије. Вук Стеф. Караџић (1787-1864-2014), Београд: САНУ: 415-429.

Радовановић 1973. М. Радовановић, Вук Караиић, етнограф и фолклорист. Београд: САНУ.

Самарџија 2013. С. Самарџија, Неке особености формула времена у лирској народној поезији, Време, вакат, земан. Аспекти времена у фолкло$p y$, пр. Л. Делић. Београд: Институт за књижевност и уметност: 241-315.

Стефановић 1933. С. Стефановић, Студије о народној поезији, I-II. Београд: Штампарија Ж. Маџаревића, $1937 .{ }^{2}$

Стефановић 1936. С. Стефановић, Сунчани мит у нашој народној поезији. Прилози проучавању народне поезије, III/1 (1936): 35-42.

Stojković 1934. M. Stojković, Vile mu srce izjele. Nastavni vjednik, XLII (1934-1935): 235-237.

Сувајџић 2005. Б. Сувајџић, Јунаци и маске. Београд: Друштво за српски језик и књижевност Србије.

Сувајџић 2007. Б. Сувајџић, Иларион Рувараи и народна књижевност. Београд: Институт за књижевност и уметност.

Сувајџић 2008. Б. Сувајџић, Жена на капијама Града. Годишььк Катедре за српску књижевност са јужнословенским књижевностима, 4. Београд: Филолошки факултет: 111-137.

Толстој 1995. Н. И. Толстој, Језик словенских култура. Ниш: Просвета. 
Толстој 2001. Н. И. Толстој, Бик. Словенска митологија, пр. С. М. Толстој - Љ. Раденковић. Броград: Zepter Book World: 25-27.

Тројановић 1983. С. Тројановић, Главни српски жртвени обичаји. Старинска српска јела и пића, пог. П. Влаховић. Београд: Просвета.

Тројановић 1986. С. Тројановић, Психофизичко изражавање српскога народа поглавито без речи, пог. Ж. Требјешанин. Београд: Просвета.

Тројановић 1990. С. Тројановић, Ватра у обичајима и животу српског народа, пог. Ж. Требјешанин. Београд: Просвета.

Ћоровић 1908. В. Ћоровић, Мјесечева женидба. Мостар: Преглед Мале библиотеке.

Чајкановић 1973. В. Чајкановић, Мит и религија у Срба. Изабране студије, пр. В. Ђурић. Београд: СКЗ.

Чајкановић 1984. В. Чајкановић, Стара српска религија и митологија, 1-5, пр. В. Ђурић. Београд: СКЗ - БИГЗ - Просвета - Партенон.

Чајкановић 1985. В. Чајкановић, Речник српских народних веровања о биљкама, пр. В. Ђурић. Београд: СКЗ.

Чајкановић 1985.а. В. Чајкановић, О магији и религији, пр. Б. Јовановић. Београд: Просвета.

Snežana D. Samardžija

\section{"ESPECIALLY MYTHOLOGICAL SONGS" IN VUK KARADŽIĆ‘S COLLECTIONS}

\section{Summary}

After reflecting on the history of research on mythological lyric in south Slavic and Serbian studies, Vuk's views on this poetic type is pointed out. Since 1841. when Vuk published the first volume of Serbian folk poems, the cycle of mythological lyric has been singled out. However, he applied the same term for a number of poems "in the middle", at the begging of the second book of Vienna edition. Only lyrical mythological poems from Vuk's collections and manuscripts are singled out on this occasion. Of particular note are the stylization of archaic layers (elemnets of cosmogony, solar and lunar cult, matriarchy) and the processes of their intertwining with christian depictions. Structural segments (different types of heroes, space, time, thematic) are singled out, along with flexibility of formulae and the dynamic genre connections of oral types.

Key words: mythological lyric poems, layers of tradition, Vuk's classification, formula, genre fusions 